\title{
STRATEGI PEMBENTUKAN LEMBAGA KEUANGAN MIKRO AGRIBISNIS (LKMA) PASCA PROGRAM PENGEMBANGAN USAHA AGRIBISNIS PERDESAAN (PUAP) DI KABUPATEN KUNINGAN
}

\author{
Kurniawati Dwimanur \\ Alumni STEI SEBI \\ \& \\ Hendro Wibowo \\ Dosen STEI SEBI
}

\begin{abstract}
ABSTRAK
Pertanian merupakan salah satu sektor andalan Indonesia dan merupakan mata pencaharian utama bagi mayoritas masyarakat Indonesia. Tenaga kerja yang banyak di bidang pertanian ini tidak diimbangi dengan perkembangan yang cukup signifikan. Kesejahteraan petani masih belum dapat tercapai. Untuk itu, pemerintah banyak menggulirkan program-program bantuan di bidang pertanian dalam rangka pengentasan kemiskinan salah satunya melalui program PUAP.
\end{abstract}

Kemiskinan di kalangan petani ini disebabkan karena lambatnya pertumbuhan di bidang pertanian disebabkan oleh sulitnya mengakses permodalan untuk mengembangkan pertanian, melalui Program PUAP diharapkan petani dapat mengembangkan usahanya dan membentuk kelembagaan ekonomi khusus petani berupa Lembaga keuangan Mikro Agribisnis (LKMA) yang dapat menyediakan kebutuhan permodalan bagi petani miskin.

Penelitan dilakukan di Kabupaten Kuningan dengan sampel 8 gapoktan yang tersebar di 6 kecamatan berbeda. Penelitian ini bertujuan untuk membuat strategi pembentukan LKMA bagi Gapoktan PUAP di Kabupaten Kuningan.

Penelitian ini merupakan jenis penelitian deskriptif dengan alat analisis yang dipakai adalah model perumusan strategi dengan metode SWOT (Strength, Weakness, Opportunity, Threat). Yaitu mengevaluasi dan menentukan faktorfaktor pen unjang dan penghambat apa saja yang berpengaruh terhadap pembentukan LKMA berdasarkan kepada analisis lingkungan internal dan eksternal. Selanjutnya berbagai alternatif strategi yang sudah didapat dari matriks SWOT diproses kembali menggunakan metode QSPM (Quantitative Strategic Planning Matrix) untuk melihat strategi mana yang menjadi prioritas utama.

Hasil penelitian menunjukan keadaan Gapoktan pada proses pembentukan LKMA saat ini berada pada kuadran I, yaitu strategi SO (Strength-Opportunity). Dari beberapa alternatif strategi pada strategi SO, urutan prioritas strtaegi setelah dilakukan QSPM adalah satu, mengembangkan usaha tani melalui pemaksimalan pemanfaatan dana bantuan dari pemerintah dengan pengembangan permodalan pada usaha tani sehingga LKMA dapat terbentuk (nilai daya tarik 6,02) dan dua, mengembangkan kelembagaan Gapoktan melalui pelatihan tekhnis pembentukan LKMA guna meningkatkan peran modal petani dan kesiapan gapoktan dalam pembentukan LKMA (nilai daya tarik 3,15).

Kata Kunci: LKMA, strategi pembentukan, Gapoktan 


\section{BAB I PENDAHULUAN}

\subsection{Latar Belakang}

Indonesia memiliki ketersediaan lahan pertanian yang besar dan potensial untuk dikembangkan dan dibudidayakan, namun hal tersebut tidak diiringi dengan kesiapan dalam mengolah lahan tersebut. Data dari Kementrian Pertanian pada tahun 2010 menyampaikan bahwa lahan yang sesuai untuk pertanian dari seluruh luas lahan daratan Indonesia adalah sekitar 94,1 juta ha dan yang sudah dijadikan lahan pertanian baru sekitar 63,7 juta ha. Dengan demikian masih terdapat sekitar 30,4 juta ha lahan sisa yang berpeluang untuk perluasan area pertanian. Dari lahan sisa yang tersedia diantaranya ada sekitar 24 juta ha lahan subur. Selain itu, hingga saat ini masih ada sekitar 12,4 juta ha lahan pertanian terlantar (Pertanian, 2009).

Menurut laporan tertulis Data Sosial Ekonomi yang dilakukan oleh Badan Pusat Statistik pada tahun 2012 menunjukan 38,82 juta orang Indonesia bekerja sebagai petani dari total 110,80 juta orang bekerja. Adapun keadaan penduduk yang bekerja diklasifikasikan berdasarkan lapangan pekerjaannya ditunjukan pada grafik 1 :

\section{Grafik1.1}

Penduduk Yang Bekerja Berdasarkan Lapangan Pekerjaan Utama

Sumber : diolah dari data ketenagakerjaan BPS, Maret 2012

Dari data statistik diatas terlihat bahwa sektor pertanian adalah sektor yang paling banyak menyerap tenaga kerja. Meskipun setiap tahun terjadi pengurangan jumlah tenaga kerja pada sektor pertanian, namun hal tersebut tidak membuat sektor pertanian tergeser dari peringkat pertama lapangan pekerjaan utama masyarakat. Akan tetapi jumlah tersebut tidak berlaku pada sumbangannya terhadap distribusi PDB Indonesia. Tahun 2012 sektor pertanian hanya menyumbang sebesar $10,5 \%$ dari total jumlah PDB Indonesia yaitu Rp 662.008,20 triliun. Berdasarkan data dari 
BPS, tahun 2012 sumbangan terhadap PDB ini mengalami penurunan yaitu dari $11,9 \%$ pada tahun 2011. Hal ini berbeda jauh dengan sektor pengolahan yang menjadi penyumbang terbesar terhadap distribusi PDB Indonesia yaitu sebesar 26,2\% (Statistik, 2012). Berikut adalah data distribusi PDB tahun 2012 berdasarkan sektor lapangan usaha pada Grafik 1.2 :

\section{Grafik1.2 \\ PDB Berdasarka Lapangan Usaha 2012}

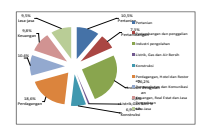

Sumber : Badan Pusat Statistik, 2012

Dari gambar diatas, kita bisa melihat bahwa sektor pertanian hanya menyumbang $10,5 \%$ terhadap distribusi PDB, urutannya berada di bawah Industri pengolahan yang menyumbang sebesar 26,2\%. Hal ini berbanding terbalik dengan kondisi penyerapan tenaga kerja dimana sektor pertanian menjadi sektor terbanyak penyerap tenaga kerja. Ini mengindikasikan bahwa pertumbuhan pertanian tidak sepesat pertumbuhan industri pengolahan.

Masalah substansial lainnya menjadi dampak dari lambatnya pertumbuhan pada sektor ini, diantaranya adalah kemiskinan yang terjadi pada mayoritas masyarakat Indonesia khususnya pada kehidupan petani. Sampai dengan tahun 2011, tingkat kemiskinan nasional memang telah dapat diturunkan menjadi $12,49 \%$ dari $13,35 \%$ pada tahun 2010 , namun angka $12 \%$ jumlah penduduk miskin ini masih termasuk dalam kategori tinggi/serius dalam tingkat kemiskinan menurut Global Hunger Index (HGI) yang menjadi acuan dunia internasional dalam mengukur jumlah penduduk miskin suatu negara. Berikut adalah tingkat kemiskinan Indonesia dari tahun $2007-2012$ :

\section{Grafik1.3}

\section{Tingkat Kemiskinan di Indonesia}




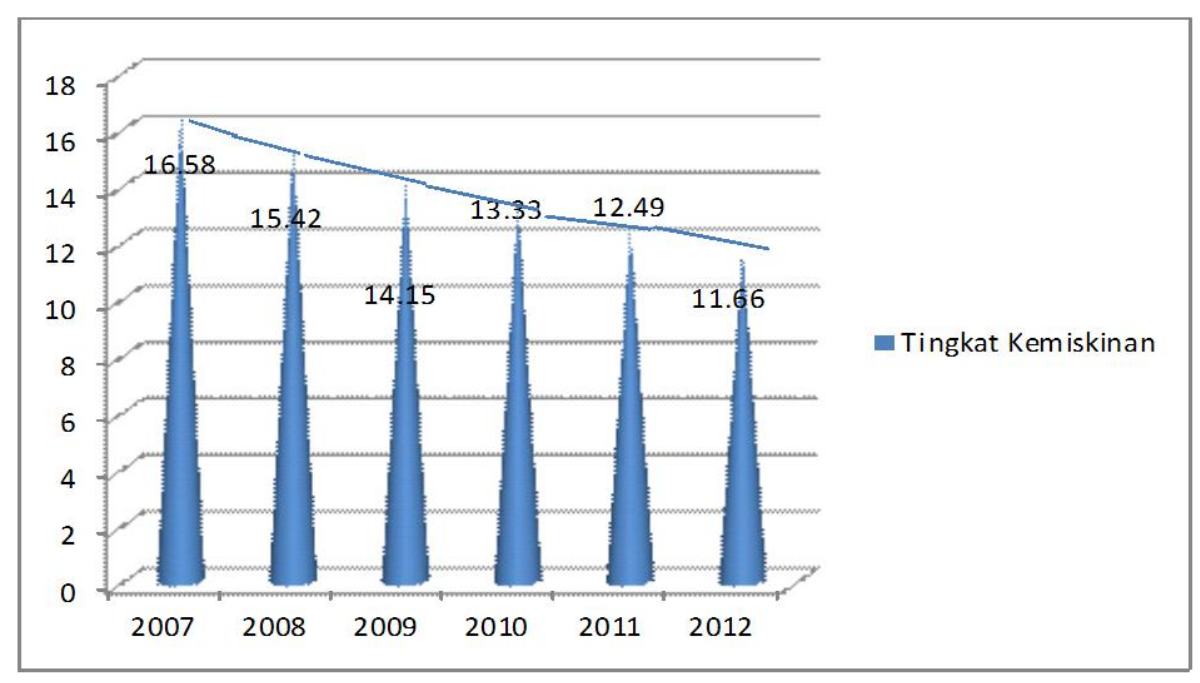

Sumber : Badan Pusat Statistik (BPS), 2012

Tingkat kemiskinan nasional tahun 2012 berada pada angka $11,66 \%$ masih termasuk dalam kategori tinggi untuk negara yang besar potensi alamnya seperti Indonesia. Kemiskinan ini merupakan permasalahan serius. Untuk mengatasi masalah ini, pemerintah menunjukkan perannya dan memberikan solusinya, yaitu dengan mengeluarkan program-program penanggulangan kemiskinan. Program ini terbagi dalam 3 klaster. Klaster I ditujukan untuk mengurangi beban pemenuhan kebutuhan dasar dan untuk memenuhi kebutuhan dasar anggota rumah tangga miskin melalui peningkatan akses pada pelayanan dasar, Klaster II bertujuan untuk pemberdayaan masyarakat dan klaster III adalah penyaluran Kredit bagi UMKM dan Koperasi, berikut adalah daftar program-program pemerintah berdasarkan klasternya :

Tabel 1.1

Daftar Program Pemerintah dalam Menanggulangi Kemiskinan

\begin{tabular}{|c|c|}
\hline Klaster & Program Pemerintah \\
\hline \multirow{4}{*}{ I } & 1. Raskin \\
\hline & 2. Jamskesmas \\
\hline & 3. Beasiswa \\
\hline & 4. Program keluarga Harapan $(\mathrm{PKH})$ \\
\hline \multirow{5}{*}{ II } & 1. $\quad$ PNPM Mandiri Inti \\
\hline & 2. $\quad$ PNPM Generasi \\
\hline & 3. PNPM Kelautan dan Perikanan (PNPM-KP) \\
\hline & 4. $\quad$ PNPM Agribisnis (PUAP) \\
\hline & 5. PNPM Pariwisata \\
\hline III & KUR \\
\hline
\end{tabular}

Sumber : TNP2K, 2012 
Dalam bidang pertanian, pemerintah menaruh harapan lebih besar, karena mayoritas penduduk Indonesia bermatapencaharian sebagai petani. Melalui PNPM Mandiri, pemerintah mengadakan Program Pengembangan Agribisnis Perdesaan (PUAP) untuk mengembangkan pertanian di daerah perdesaan. Pemerintah Indonesia melalui Kementerian Pertanian mulai tahun 2008 telah melaksanakan program Pengembangan Usaha Agribisnis Perdesaan (PUAP) di bawah koordinasi Program Nasional Pemberdayaan Masyarakat Mandiri (PNPM-Mandiri). Dari tahun 2008 sampai sekarang dana PUAP terus digulirkan oleh pemerintah guna terus meningkatkan sektor agribisnis. Berikut adalah data perkembangan dana PUAP nasional dari tahun 2008 - 2012 :

Tabel 1.2 Perkembangan Dana PUAP Tahun 2008 - 2012

\begin{tabular}{|c|c|c|c|}
\hline Tahun & $\begin{array}{c}\text { Jumlah Kab/Kota } \\
\text { PUAP }\end{array}$ & $\begin{array}{c}\text { Jumlah Gapoktan } \\
\text { penerima PUAP }\end{array}$ & Jumlah dana PUAP \\
\hline 2008 & $389 \mathrm{Kab} /$ Kota & 10.542 Gapoktan & 1,053 triliun \\
\hline 2009 & $421 \mathrm{Kab} /$ Kota & 9.884 Gapoktan & 988,304 milyar \\
\hline 2010 & $444 \mathrm{Kab} /$ Kota & 8.587 Gapoktan & 858,7 milyar \\
\hline 2011 & $445 \mathrm{Kab} /$ Kota & 9110 Gapoktan & 911 milyar \\
\hline 2012 & - & 6.050 Gapoktan & 605 milyar \\
\hline
\end{tabular}

Sumber : diolah dari data Gapoktan Deptan

Data di atas menunjukkan bahwa setiap tahunnya PUAP mulai berkembang di pelosok negeri, hal ini bisa terlihat dari terus bertambahnya jumlah Kabupaten/Kota yang mendapatkan dana PUAP. Pada tahun 2008 PUAP hanya digulirkan pada 389 Kabupaten/Kota, namun tahun selanjutnya terus mengalami peningkatan yaitu mencapai 421 Kabupaten/Kota pada 2009 dan 444 Kabupaten/Kota pada 2010 dan 445 Kabupaten/Kota pada tahun 2011.

Menurut data dari Badan Penyuluhan Pertanian, Peternakan, Perikanan dan Kehutanan (BP4K) di Kabupaten Kuningan Provinsi Jawa Barat yang merupakan tim tekhnis yang menangani pelaksanaan program PUAP dari Kementan Kabupaten Kuningan, peningkatan jumlah Gapoktan/Desa yang menerima dana PUAP juga terjadi tiap tahunnya. Ini merupakan salah satu indikasi bahwa program PUAP di daerah pun terus berkembang. Berikut data perkembangan PUAP di Kabupaten Kuningan, Jawa Barat :

Tabel 1.3 Perkembangan Dana PUAP Tahun 2008 - 2011

\begin{tabular}{|c|c|c|c|c|}
\hline Tahun & $\begin{array}{c}\text { Jumlah Desa } \\
\text { PUAP }\end{array}$ & $\begin{array}{c}\text { Jumlah Gapoktan } \\
\text { PUAP }\end{array}$ & $\begin{array}{c}\text { Jumlah dana } \\
\text { PUAP }\end{array}$ & $\begin{array}{c}\text { Jumlah } \\
\text { LKMA } \\
\text { PUAP }\end{array}$ \\
\hline 2008 & 33 Desa & 33 Gapoktan & 3,3 milyar & 3 LKMA \\
\hline 2009 & 62 Desa & 62 Gapoktan & 6,2 milyar & 6 LKMA \\
\hline 2010 & 81 Desa & 81 Gapoktan & 8,1 milyar & 7 LKMA \\
\hline 2011 & 119 Desa & 119 Gapoktan & 11,9 milyar & 8 LKMA \\
\hline
\end{tabular}

Sumber : diolah dari daflok PUAP Kab.Kuningan,2011 
Jumlah Gapoktan PUAP Kabupaten Kuningan pada tahun 2011 mencapai 119 Gapoktan, namun pembentukan LKMA sebagai output dari digulirkannya PUAP baru ada 8 LKMA yang berhasil terbentuk. Perkembangan pembentukan LKMA Kabupaten Kuningan dari tahun ke tahun pun tidak signifikan, tahun 2008 terbentuk 3 LKMA, 2009 terbentuk 3 LKMA, 2010 hanya terbentuk 1 LKMA dan 2011 juga tak mengalami peningkatan yaitu hanya terbentuk 1 LKMA (BP4K, 2012). Ini tentunya menjadi hal yang kontras dengan pertumbuhan jumlah desa penerima PUAP. Gapoktan yang terbentuk yang merupakan kelembagaan petani harusnya menjadi titik awal untuk terbentuknya LKMA. PUAP yang telah berjalan dari tahun 2008 perlu dievaluasi untuk penyempurnaan pelaksanaannya sehingga bisa diketahui kelemahan dalam pelaksanaan selama ini sehingga akan terdapat kesimpulan tentang perencanaan strategsi pembentukan Lembaga Keuangan Mikro Agribisnis sebagai output dari pelaksanaan PUAP ini. Oleh karena itu, penulis tertarik untuk mengadakan penelitian dengan judul "STRATEGI PEMBENTUKAN LEMBAGA KEUANGAN MIKRO AGRIBISNIS (LKM-A) PASCA PROGRAM PENGEMBANGAN USAHA AGRIBISNIS PERDESAAN (PUAP) DI KABUPATEN KUNINGAN".

\subsection{Rumusan Masalah}

Berdasarkan data yang diperoleh oleh penulis, pertumbuhan pembentukan LKM-A dari 2008-2011 hanya sebesar 6,7\%. Fakta lapangan ini memberi pertanyaan besar tentang pelaksanaan program PUAP di Kabupaten Kuningan dan perencanaan strategisnya. Maka rumusan masalah dalam penelitian adalah sebagai berikut : Bagaimanakah strategi pembentukan LKM-A sebagai output dari PUAP di Kabupaten Kuningan?

\subsection{Tujuan Penelitian}

Dari permasalahan yang diangkat dalam penulisan ini, tujuan dari penelitian ini adalah : Untuk mengetahui strategi pembentukan LKM-A sebagai output dari pelaksanaan program PUAP di Kabupaten Kuningan.

\subsection{Batasan masalah}

Penelitian ini terbatas pada program PUAP, dimana program bantuan ini memiliki orientasi pemberdayaan kelembagaan petani yang salah satunya adalah terbentuknya Lembaga Keuangan Mikro Agribisnis (LKMA). Lokasi yang dipilih adalah wilayah yang telah melaksanakan program PUAP dan belum membentuk LKMA tahun 2008,2009 dan 2010 dalam hal ini penulis memilih wilayah Kabupaten Kuningan Jawa Barat. Gapoktan yang diteliti dibatasi setiap tahunnya. Tahun 2008 diteliti 3 Gapoktan, 3 Gapoktan pada 2009 dan 2 Gapoktan pada 2010, sehingga total Gapoktan yang diteliti dalam penelitian ini adalah 8 Gapoktan. 


\section{BAB II LANDASAN TEORI}

\subsection{Program Pengembangan Usaha Agribisnis Pertanian (PUAP)}

\subsubsection{Latar Belakang Program}

Pengembangan Usaha Agribisnis Pedesaan yang selanjutnya disebut PUAP merupakan bentuk fasilitasi bantuan modal usaha untuk petani yang tergabung dalam kelompok - kelompok tani, baik petani pemilik, petani penggarap, buruh tani maupun rumah tangga tani. Gabungan Kelompok Tani yang selanjutnya disebut Gapoktan merupakan kelembagaan tani pelaksana PUAP untuk penyaluran bantuan modal usaha bagi anggota. Dalam pelaksanaan program, Gapoktan didampingi oleh tenaga Penyuluh Pendamping dan Penyelia Mitra Tani (PMT), sehingga diharapkan Gapoktan dapat menjadi kelembagaan ekonomi yang dimiliki dan dikelola petani (Pedum, 2012).

\subsubsection{Tujuan Program}

Ada beberapa tujuan dari pengelenggaraan program, di antaranya:

a. Mengurangi kemiskinan dan penganguran melalui penumbuhan dan pengembangan kegiatan usaha agribisnis dipedesaan sesuai dengan potensi wilayah;

b. Meningkatkan kemampuan pelaku usaha agribisnis Pengurus Gapoktan, Penyuluh dan Penyelia Mitra Tani;

c. Memberdayakan kelembagaan petani dan ekonomi pedesaan untuk pengembangan kegiatan usaha agribisnis;

d. Meningkatkan fungsi kelembagaan ekonomi petani menjadi jaringan atau mitra lembaga keuangan dalam rangka akses permodalan.

\subsubsection{Sasaran Program}

Sasaran program PUAP :

a. Berkembangnya usaha agribisnis di 10.000 desa miskin / tertinggal sesuai dengan potensi pertanian desa;

b. Berkembangnya Gapoktan yang dimiliki dan dikelola oleh petani untuk menjadi kelembagaan ekonomi;

c. Meningkatnya kesejahteraan rumah tangga tani miskin, petani/peternak (pemilik dan atau penggarap) skala kecil dan buruh tani;

d. Berkembanganya usaha agribisnis petani yang mempunyai siklus usaha harian, mingguan maupun musiman;

\subsubsection{Indikator Keberhasilan}

Indikator keberhasilan output antara lain :

a. Tersalurkannya dana BLM PUAP kepada petani, buruh tani dan rumah tangga tani miskin anggota Gapoktan sebagai modal untuk melakukan usaha produktif pertanian; dan 
b. Terlaksanya fasilitasi penguatan kapasitas dan kemampuan sumber daya manusia pengelola Gapoktan, Penyuluh Pn]endamping dan Penyelia Mitra Tani.

Indikator keberhasilan outcome antara lain :

a. Meningkatnya kemampuan Gapoktan dalam memfasilitasi dan mengelola bantuan modal usaha untuk petani anggota baik pemilik, petani penggarap, buruh tani maupun rumah tangga tani;

b. Meningkatnya jumlah petani, buruh tanu dan rumah tangga tani yang mendapatkan bantuan modal usaha;

c. Meningkatnya aktivitas kegiatan usaha agribisnis (hulu, budidaya dan hilir) di perdesaan; dan

d. Meningkatnya pendapatan petani (pemilik dan atau penggarap), buruh tani dan rumah tangga tani dalam berusaha tani sesuai dengan potensi daerah.

Sedangkan indikator keberhasilan benefit dan Impact antara lain :

a. Berkembangnya usaha agribisnis dan usaha ekonomi rumah tangga tani di lokasi desa PUAP

b. Berfungsinya Gapoktan sebagai lembaga ekonomi petani di perdesaan yang dimiliki dan dikelola oleh petani; dan

c. Berkurangnya jumlah petani miskin dan pengangguran di perdesaan.

\subsection{Manajemen Strategi}

Manajemen strategis telah banyak dibahas oleh para ahli mengingat pentingnya peran manajemen strategis dalam sebuah perusahaan atau organisasi, berikut adalah pengertian - pengertian manajemen strategis menurut para ahli :

- Menurut William F.Glueck - Lawarence R.Jauch : “ Manajemen strtaegi merupakan arus keputusan dan tindakan yang mengarah pada perkembangan suatu strategi atau strategi - strategi yang efektif untuk membantu mencapai sasaran perusahaan. Proses manajemen strategi ialah suatu cara dengan jalan bagaimana para perencana strategi menentukan sasaran untuk membuat kesimpulan strategi (Jauch, 1996).”

- Menurut Thomas L.Wheelen - J.David Hunger : “ Manajemen strategi adalah serangkaian keputusan manajerial dan kegiatan kegiatan yang menentukan keberhasilan perusahaan dalam jangka panjang. Kegiatan tersebut terdiri dario perumusan / perencanaan strategi, pelaksanaan / implementasi, dan evaluasi (Purwanto, 1999) (Purwanto, 1999)."

- Menurut Gregory G.Dess - Alex Miller : “ Manajemen strategi adalah suatu proses kombinasi antara tiga aktivitas, yaitu analisis strategi, perumusan strategi dan implementasi strategi (Purwanto, 1999)." 
- Menurut Chareles W.L.Hill - Gareth R.Jones : “ Manajemen strategi adalah individu - individu yang bertanggung jawab secara keseluruhan daripada organisasi atau bertanggung jawab merumuskan satu tugas utana dari divisi - divisi.

- Adapun manajemen strategi menurut Fred R.David dalam bukunya Manajemen Strategis Edisi 10 dapat didefinisikan sebagai seni dan ilmu untuk memformulasi, mengimplementasi dan mengevaluasi keputusan lintas fungsi yang memungkinkan organisasi dapat mencapai tujuannya (R.David, 2006).

Evaluasi strategi meliputi tiga aktivitas dasar yaitu : memeriksa dasar strategi organisasi, membandingkan hasil yang diharapkan dengan hasil aktual, dan mengambil tindakan korektif untuk memastikan kinerja sejalan dengan rencana. Evaluasi dilakukan secara menyeluruh pada sebuah program atau organisasi, evaluasi ini dilakukan baik pada faktor Internal ataupun Eksternal. Faktor Internal terdiri dari kekuatan dan kelemahan yang dimiliki sedangkan faktor eksternal terdiri dari peluang dan ancaman yang berasal dari luar organisasi. Faktor internal dan eksternal ini dapat dianalisis menggunakan Matriks EFE dan matriks IFE.

\subsection{Agribisnis}

Pengertian agribisnis yang digunakan di negara-negara Asia adalah konsep yang dikemukakan oleh Davis \& Golberg (1957), dan diperkenalkan di Thailand, Malaysia dan Filiphina sekitar dekade 1960an. Di Indonesia, agribisnis baru diperkenalkan secara resmi pada tahun 1984 ketika didirikan Studi Agribisnis di Jurusan Sosial Ekonomi Pertanian, Fakultas Pertanian, Institut Pertanian Bogor dan mulai populer pada awal dekade 1990-an dalam berbagai media massa nasional, forumforum, dan diskusi-diskusi pakar. Para pakar nasional saat itu menyatakan bahwa pengembangan agribisnis Indonesia harus menjadi prioritas dalam Pembangunan Nasional Jangka Panjang. Definisi agribisnis yang dikemukakan oleh Davis \& Golberg (1957) memberikan suatu konsep dan wawasan yang sangat dalam tentang pertanian modern menghadapi masa milenium (Erickson, 1992).

\subsection{Lembaga Keuangan Mikro}

Menurut definisi yang dipakai dalam Microcredit Summit (1997) yang dituliskan dalam tulisan Wijono Pemberdayaan Lembaga Keuangan Mikro Sebagai Salah Satu Pilar Sistem Keuangan Nasional : Upaya Kongkrit Memutus Mata Rantai Kemiskinan, kredit mikro adalah program pemberian kredit berjumlah kecil ke warga paling miskin untuk membiayai proyek yang dia kerjakan sendiri agar menghasilkan pendapatan, yang memungkinkan mereka peduli terhadap diri sendiri dan keluarganya (Wijono). Menurut Asian Cevelopment Bank (ADB), lembaga keuangan mikro (micro finance) adalah lembaga yang menyediakan jasa penyimpanan (depoosit), kredit (loan), pembayaran 
berbagai transaksi jasa (payment service) serta money transfer yang ditujukan bagi masyarakat miskin dan pengusaha kecil. Sedangkan bentuk LKM dapat berupa lembaga formal misalnya bank desa dan koperasi atau lembaga nonformal misalnya organisasi non pemerintah atau dapat pula berbentuk sumber-sumber informal lainnya usalnya pelepas uang.

\section{BAB III METODOLOGI PENELITIAN}

\subsection{Jenis Penelitian}

Jenis penelitian yang digunakan dalam penelitian ini adalah penelitian kualitatif deskriptif. Menurut Arikunto (2005:234), penelitian deskriptif adalah penelitian yang dilakukan untuk mengetahui nilai variabel mandiri, baik satu variabel ataupun lebih tanpa membuat perbandingan atau menghubungkan dengan variabel lain pada saat penelitian dilakukan (Suharsimi, 2002). Dalam penelitian ini digambarkan tentang kondisi pelaksanaan program PUAP yang digulirkan pemerintah secara sistematis, mulai dari tingkat pusat sampai tingkat desa, serta menggambarkan secara faktual sesuai dengan yang ada di lapangan.

\subsection{Objek Penelitian}

Menurut Sugiyono (2009:38) objek penelitian adalah suatu atribut atau sifat atau nilai dari orang, objek atau kegiatan yang mempunyai variasi tertentu yang ditetapkan oleh peneliti untuk di pelajari dan kemudian ditarik kesimpulannya. Objek penelitian pada penelitian ini adalah Gapoktan yang menerima dana PUAP di wilayah Kabupaten Kuningan yang belum membentuk lembaga keuangan Mikro Agribisnis.

\subsection{Populasi}

Menurut Sugiyono (2009:215) populasi adalah wilayah generalisasi yang terdiri atas obyek atau subyek yang mempunyai kualitas dan karakteristik tertentu yang ditetapkan oleh peneliti untuk dipelajari dan kemudian ditarik kesimpulannya. Maka populasi dari penelitian ini adalah Gapoktan PUAP di Kabupaten Kuningan yang menerima dana bantuan PUAP pada tahun 2008, 2009, 2010 yang belum menjadi lembaga keuangan mikro agribisnis dengan total jumlah 74 Gapoktan yang tersebar di 30 kecamatan dan terkoordinasi di bawah 15 Unit BP3K.

Tabel 3.1

Data Jumlah Gapoktan PUAP Kabupaten Kuningan Tahun 2008 2010

\begin{tabular}{|l|l|c|c|c|}
\hline No. & \multicolumn{1}{|c|}{ Unit BP3K } & $\begin{array}{c}\text { Jumlah } \\
\text { Kecamatan }\end{array}$ & $\begin{array}{c}\text { Jumlah } \\
\text { Gapoktan } \\
\text { (non-LKM) }\end{array}$ & $\begin{array}{c}\text { Jumlah } \\
\text { Gapoktan } \\
\text { (LKM) }\end{array}$ \\
\hline 1. & Ciawigebang & 2 & 8 & - \\
\hline 2. & Cibingbin & 2 & 6 & - \\
\hline 3. & Cigugur & 2 & 4 & 1 \\
\hline
\end{tabular}




\begin{tabular}{|c|c|c|c|c|}
\hline 4. & Darma & 2 & 8 & 2 \\
\hline 5. & Ciwaru & 2 & 4 & - \\
\hline 6. & Luragung & 2 & 7 & - \\
\hline 7. & Kuningan & 2 & 4 & - \\
\hline 8. & Garawangi & 1 & 6 & - \\
\hline 9. & Jalaksana & 2 & 5 & - \\
\hline 10. & Mandirancan & 3 & 4 & 2 \\
\hline 11. & Ciniru & 2 & 6 & - \\
\hline 12. & Cilimus & 2 & 5 & 1 \\
\hline 13. & Cidahu & 1 & 2 & 1 \\
\hline 14. & Subang & 3 & 2 & - \\
\hline 15. & Lebakwangi & 2 & 2 & - \\
\hline & Total & 30 & 74 & 7 \\
\hline
\end{tabular}

Sumber: Daflok PUAP Kab. Kuningan (diolah)

\subsection{Sampel}

Pengertian sampel menurut Suharsimi Arikunto (2005:109) adalah bagian dari populasi (sebagian atau wakil populasi yang diteliti). Sedangkan dalam bukunya Sugiyono (2012:216) disebutkan bahwa sampel dalam penelitian kualitatif tidak disebut sebagai responden, tetapi sebagai narasumber dalam penelitian. Sampel dalam penelitian kualitatif juga disebut sebagai sampel teoritis, karena tujuan dari penelitian kualitatif adalah menghasilkan teori (Sugiyono, Metode penelitian kombinasi, 2012).

Berdasarkan pengertian di atas, maka yang menjadi sampel dalam penelitian ini adalah 8 Gapoktan dari tahun 2008-2010 dengan proporsi yang berbeda tiap tahunnya. Tahun 2008 diambil 3 Gapoktan sampel, tahun 2009 diambil 3 gapoktan sampel dan tahun 2010 diambil 2 gapoktan sampel. Kedelapan gapoktan ini tersebar di 6 UPT BP3K berbeda, yaitu di UPT BP3K Cigugur, Mandirancan, Garawangi, Ciawigebang, Kuningan dan Lebakwangi, penarikan sampel ini diperlukan karena peneliti mempunyai keterbatasan dalam menjangkau seluruh populasi

Tabel 3.2

Daftar Gapoktan PUAP sampel tahun 2008 - 2010

\begin{tabular}{|c|c|c|c|c|}
\hline $\begin{array}{l}\text { Tahu } \\
\text { n }\end{array}$ & $\begin{array}{l}\text { Nama } \\
\text { Gapoktan }\end{array}$ & Desa & $\begin{array}{l}\text { Kecamata } \\
\text { n }\end{array}$ & $\begin{array}{l}\text { UPT } \\
\text { BP3K }\end{array}$ \\
\hline 2008 & $\begin{array}{ll}\text { 1. } & \text { Makmur } \\
\text { 2. } & \text { Harapan } \\
& \text { Mekar } \\
\text { 3. } & \text { Gandawan } \\
\text { gi }\end{array}$ & $\begin{array}{l}\text { Cileuleuy } \\
\text { Sindangkempe } \\
\text { ng } \\
\text { Garawangi }\end{array}$ & $\begin{array}{l}\text { Cigugur } \\
\text { Pancalang } \\
\text { Garawangi }\end{array}$ & $\begin{array}{l}\text { Cigugur } \\
\text { Mandiranc } \\
\text { an } \\
\text { Garawangi }\end{array}$ \\
\hline 2009 & $\begin{array}{ll}\text { 1. } & \text { Taruna } \\
\text { Mukti }\end{array}$ & $\begin{array}{l}\text { Sukamukti } \\
\text { Ciketak } \\
\text { Tinggar }\end{array}$ & $\begin{array}{l}\text { Cipicung } \\
\text { Kadugede } \\
\text { Kadugede }\end{array}$ & $\begin{array}{l}\text { Ciawigeba } \\
\text { ng } \\
\text { Kuningan }\end{array}$ \\
\hline
\end{tabular}




\begin{tabular}{|l|ll|l|l|l|}
\hline & 3. & Mayana & & & Kuningan \\
\hline 2010 & 1. & Jaya & Mukti & Buni Asih & Muncangela \\
& 2. & Dewi Sri & & $\begin{array}{l}\text { Maleber } \\
\text { Cipicung }\end{array}$ & $\begin{array}{l}\text { Lebakwang } \\
\text { i } \\
\text { Ciawigeba } \\
\text { ng }\end{array}$ \\
\hline
\end{tabular}

Sumber : Daflok PUAP BP4K, diolah

\subsection{Teknik Pengambilan Sampel}

Teknik pengambilan sampel dalam penelitian ini adalah simple random sampling dan cluster sampling. Menurut Sugiyono (2008:82) simple random sampling adalah pengambilan anggota sampel dari populasi yang dilakukan secara acak tanpa memperhatikan strata yang ada dalam populasi itu. Selain random sampling dipakai juga cluster sampling, yaitu metode pengambilan sampel dengan menentukan besaran samoel yang diambil kedua metode ini dipakai karena disesuaikan dengan kondisi objek penelitian yang homogen dan ketersediaan data pada objek yang dapat mendukung penelitian.

Sampel dalam penelitian ini diambil berdasarkan tahun terbentuknya Gapoktan PUAP, menurut Pamela L.Alreck dan Robert B.Seetle dalam buku The Survey Research Handbook, untuk populasi yang besar, sampel minimum kira-kira 100 responden dan sampel maksimum adalah 1000 responden atau 10\% dari jumlah populasi.

\subsection{Jenis Data}

Data yang digunakan dalam penelitian ini adalah data yang bersifat kualitatif dan kuantitatif yang bersumber dari data primer dan data sekunder. Data primer merupakan data yang diperoleh dan dikumpul langsung ke lapangan oleh penulis, data primer ini adalah data baru yang diperoleh melalui hasil observasi dan wawancara pada pihak terkait, yaitu ke Dinas Pertanian Kabupaten Kuningan, BP4K Kabupaten Kuningan, BP3K Kecamatan dan Gapoktan. Sedangkan data sekunder adalah data yang diperoleh dan dikumpulkan oleh peneliti melalui data-data yang telah ada yang kemudian diolah kembali oleh peneliti. Data sekunder ini berasal dari sumber yang dapat dipercaya dan dipertanggungjawabkan secara ilmiah yaitu dengan melakukan studi pustaka dan penelusuran melalui internet.

\subsection{Teknik Pengumpulan Data}

Teknik pengumpulan data yang digunakan dalam penelitian ini disesuaikan dengan sumber data yang diambil, karena itu ada beberapa metode yang digunakan dalam penelitian ini, diantaranya adalah : 
1. Wawancara

Dalam buku Sugiyono (2012:231), Esterberg (2002) mendefinisikan bahwa wawancara adalah merupakan pertemuan dua orang untuk bertykar informasi dan ide melalui tanya jawab , sehingga dapat dikonstruksikan makna dalam suatu topik tertentu (Sugiyono, Metode penelitian kombinasi, 2012). Wawancara yang dilakukan kepada Dinas Pertanian Kabupaten Kuningan. Wawancara juga dilakukan pada tim tekhnis PUAP Kabupaten Kuningan yang berkedudukan di BP4K Kabupaten Kuningan dan Penyelia Mitra PUAP Kabupaten Kuningan serta Gapoktan pelaksana PUAP di Kabupaten Kuningan.

2. Observasi

Nasution (1988) dalan buku Sugiyono (2012:226) menyebutkan bahwa observasi adalah dasar semua ilmu pengetahuan. Observasi adalah kemampuan seseorang untuk menggunakan pengamatannya melalui hasil kerja pancaindera mata serta dibantu dengan pancaindera lainnya (Sugiyono, Metode penelitian kombinasi, 2012). Observasi yang dilakukan penulis berpusat pada kegiatan yang dilakukan pelaksana PUAP, yaitu Gapoktan dan BP4K Kabupaten Kuningan sebagai tim teknis PUAP. Dalam penelitian ini, penulis mengamati kegiatan yang dilakukan tim teknis PUAP Kabupaten Kuningan dengan mengikuti kegiatan-kegiatannya serta mengamati pelaksanaan Gapoktan di tingkat paling bawah yaitu kegiatan Pengurus Gapoktan di desa.

3. Kuisioner (Angket)

Menurut Sugiyono (2012:142) kuisioner merupakan teknik pengumpulan data yang dilakukan dengan cara memberi seperangkat pertanyaan atau pernyataan tertulis kepada responden untuk dijawabnya (Sugiyono, Metode penelitian kombinasi, 2012). Kuisioner ini digunakan untuk mengumpulkan data yang berkaitan langsung dengan kondisi internal dan eksternal pelaksana PUAP, sehingga kuisioner ini diberikan pada Gapoktan Penerima PUAP di kabupaten Kuningan dan BP4K Kabupaten Kuningan sebagai tim teknis pelaksana PUAP Kabupaten Kuningan.

\subsection{Analisis Data}

Analisis diawali dengan melakukan wawancara terbuka untuk mengetahui faktor-faktor apa saja yang sesuai untuk diangkat sebagai faktor-faktor dalam penelitian dan sesuai dengan keadaan Gapokan yang sebenarnya baik internal maupun eksternal. Setelah wawancara terstruktur dilakukan maka akan didapat faktor-faktor apa saja yang menjadi kelemahan, kekuatan, ancaman atau peluang. Dari hasil wawancara terstruktur ini kemudian dilanjutkan dengan analisis faktor internal dan 
eksternal secara terpisah menggunakan matriks EFE dan IFE. Setelah tahap input selanjutnya dilakukan tahap pencocokan melalui matriks SWOT.

\section{Tabel 3.3}

Matriks SWOT

\begin{tabular}{|c|c|c|}
\hline Kaktor Internal & $\begin{array}{l}\text { KEKUATAN-S } \\
\text { (daftar kekuatan) }\end{array}$ & $\begin{array}{l}\text { KELEMAHAN-W } \\
\text { (daftar kelemahan) }\end{array}$ \\
\hline Faktor Eksterna & & \\
\hline $\begin{array}{l}\text { PELUANG-O } \\
\text { (daftar peluang) }\end{array}$ & $\begin{array}{l}\text { STRATEGI S-O } \\
\text { (gunakan kekuatan } \\
\text { untuk mendapatkan } \\
\text { peluang) }\end{array}$ & $\begin{array}{l}\text { STRATEGI W-O } \\
\text { (atasi kelemahan } \\
\text { dengan memanfaatkan } \\
\text { peluang) }\end{array}$ \\
\hline $\begin{array}{l}\text { ANCAMAN-T } \\
\text { (daftar ancaman) }\end{array}$ & $\begin{array}{l}\text { STRATEGI S-T } \\
\text { (gunakan kekuatan } \\
\text { untuk menghindari } \\
\text { ancaman) }\end{array}$ & $\begin{array}{l}\text { STRATEGI W-T } \\
\text { (meminimalkan } \\
\text { kelemahan dan } \\
\text { menghindari } \\
\text { ancaman) }\end{array}$ \\
\hline
\end{tabular}

\section{BAB IV PEMBAHASAN}

\subsection{Perumusan Strategi}

Perumusan alternatif strategi terdiri dari tiga tahap, yaitu : (1) Tahap Input ; (2) tahap penggabungan; serta (3) tahap pengambilan keputusan. Metode yang digunakan dalam merumuskan strategi adalah analisis SWOT (Strength, Weakness, Opportunity, Threat) dan QSPM (Quantitative Strategic Planning Matrix). Berdasarkan hasil analisis lingkungan eksternal dan internal maka terbentuk matriks SWOT dengan terklasifikasikan yang disajikan dalam tabel berikut :

Tabel 4.1 Matriks SWOT

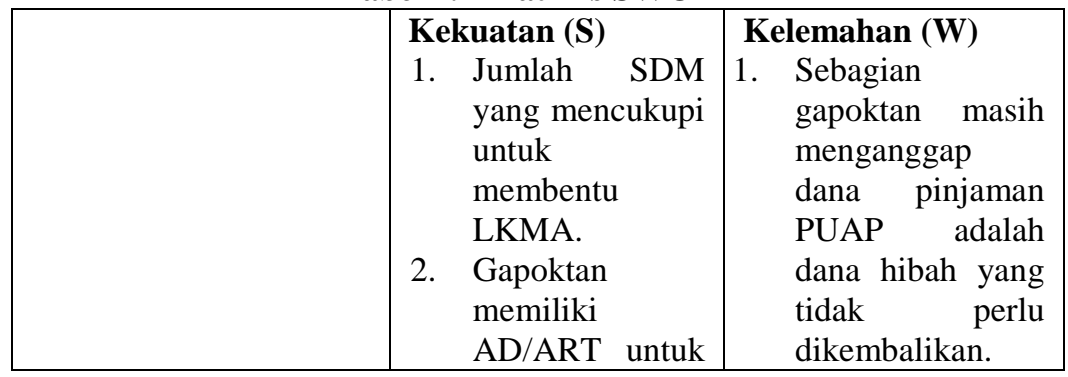




\begin{tabular}{|c|c|c|}
\hline & 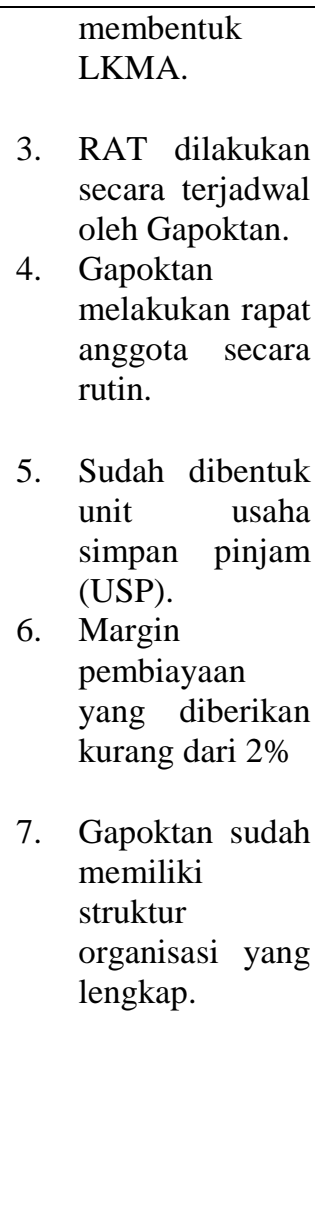 & 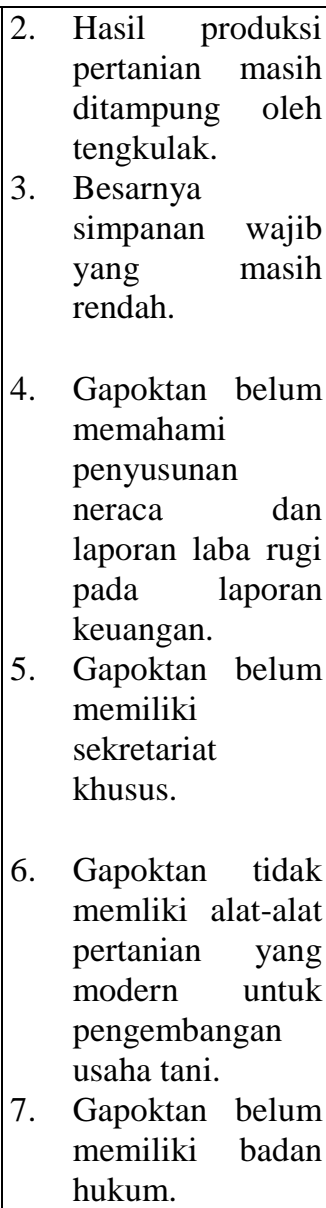 \\
\hline $\begin{array}{l}\text { Peluang (O) } \\
\text { 1. Adanya dukungan } \\
\text { dana dari } \\
\text { pemerintah pada } \\
\text { tahun } 2013 \text { untuk } \\
\text { pengembangan } \\
\text { LKMA. } \\
\text { 2. } \begin{array}{l}\text { Dilakukannya } \\
\text { pembinaan secara } \\
\text { intensif oleh } \\
\text { penyuluh terhadap } \\
\text { Gapoktan tentang } \\
\text { pembentukan }\end{array}\end{array}$ & STRATEGI S-O & STRATEGI W-O \\
\hline
\end{tabular}




\begin{tabular}{|c|c|c|c|}
\hline 4. & $\begin{array}{l}\text { LKMA. } \\
\text { Belum ada lemgaba } \\
\text { keuangan lain } \\
\text { seperti LKMA yang } \\
\text { khusus menangani } \\
\text { pertanian. } \\
\text { Kondisi geografis } \\
\text { yang mendukung } \\
\text { pengembangan } \\
\text { pertanian. }\end{array}$ & & \\
\hline \multicolumn{2}{|c|}{ Ancaman (T) } & \multirow{4}{*}{ STRATEGI S-T } & \multirow{4}{*}{ STRATEGI W-T } \\
\hline & $\begin{array}{l}\text { Tingkat resiko yang } \\
\text { tinggi pada usaha } \\
\text { pertanian }\end{array}$ & & \\
\hline & $\begin{array}{l}\text { Tidak adanya } \\
\text { pelatihan khusus } \\
\text { pengelolaan usaha } \\
\text { simpan pinjam. }\end{array}$ & & \\
\hline & \begin{tabular}{lr}
\multicolumn{2}{l}{ Rendahnya } \\
investasi dinkat \\
pertanian & sektor \\
hanya & mencapai \\
$0,23 \%$. & \\
Masih banyaknya \\
rentenir.
\end{tabular} & & \\
\hline
\end{tabular}

\subsubsection{Tahap Input}

Setelah tahap analisis maka data yang didapat diolah dalam tahap pengumpulan data. Tahap pengumpulan data adalah tahap dimana informasi internal dan eksternal dikumpulkan yang kemudian diolah dengan cara pembobotan menggunakan matriks EFE (Eksternal Factor Evaluation) dan matriks IFE (Internal Factor Evaluation).

\subsubsection{Matriks EFE}

Matriks EFE atau matriks evaluasi faktor eksternal digunakan untuk meringkas dan mengevaluasi informasi ekonomi, sosial, budaya, demografis, lingkungan politik, pemerintahan, hukum, teknologi dan kompetitif. Berikut adalah matriks EFE Gapoktan PUAP Kabupaten Kuningan : 
Tabel 4.17 Matriks EFE Gapoktan Kabupaten Kuningan

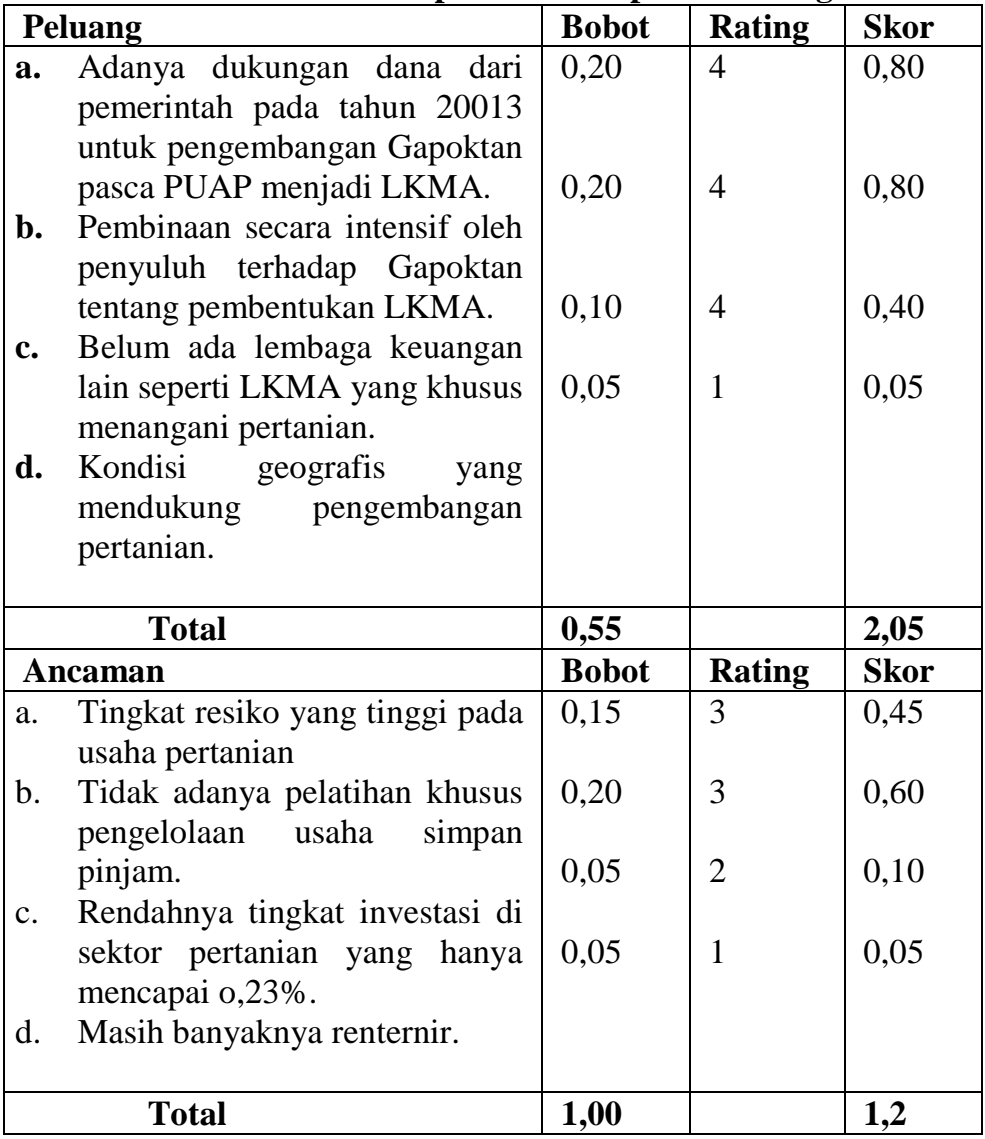

4.1.1.2 Matriks IFE

Matriks IFE atau matriks evaluasi faktor internal digunakan untuk menganalisis pengaruh faktor-faktor internal yang terdiri dari kekuatan dan kelemahan. Berikut adalah matriks evaluasi internal Gapoktan Kabupaten Kuningan :

Tabel 4.18 Matriks IFE Gapoktan Kabupaten Kuningan

\begin{tabular}{|l|l|l|l|}
\hline Kekuatan & Bobot & Rating & Skor \\
\hline $\begin{array}{l}\text { a. Jumlah SDM yang mencukupi untuk } \\
\text { membentuk LKMA. }\end{array}$ & 0,08 & 4 & 0,32 \\
b. $\begin{array}{l}\text { Gapoktan memiliki AD/ART untuk } \\
\text { membentuk LKMA. }\end{array}$ & 0,06 & 3 & 0,18 \\
c. $\begin{array}{l}\text { RAT dilakukan secara terjadwal } \\
\text { oleh Gapoktan. } \\
\text { Gapoktan melakukan rapat anggota } \\
\text { secara rutin. }\end{array}$ & 0,10 & 2 & 0,15 \\
\hline
\end{tabular}




\begin{tabular}{|c|c|c|c|}
\hline $\begin{array}{l}\text { e. Sudah dibentuk unit usaha simpan } \\
\text { pinjam (USP). } \\
\text { f. Margin pembiayaan yang diberikan } \\
\text { kurang dari } 2 \% \\
\text { g. Gapoktan sudah memiliki struktur } \\
\text { organisasi yang lengkap. }\end{array}$ & 0,05 & 1 & 0,05 \\
\hline Total & $\mathbf{0 , 5 6}$ & & 1,42 \\
\hline Kelemahan & Bobot & Rating & Skor \\
\hline $\begin{array}{l}\text { a. Sebagian gapoktan masih } \\
\text { menganggap dana pinjaman PUAP } \\
\text { adalah dana hibah yang tidak perlu } \\
\text { dikembalikan. }\end{array}$ & 0,10 & 4 & 0,40 \\
\hline $\begin{array}{l}\text { b. Hasil produksi pertanian masih } \\
\text { ditampung oleh tengkulak. }\end{array}$ & 0,03 & 4 & 0,12 \\
\hline $\begin{array}{l}\text { c. Besarnya simpanan wajib yang } \\
\text { masih rendah. }\end{array}$ & 0,09 & 4 & 0,36 \\
\hline $\begin{array}{l}\text { d. Gapoktan belum memahami } \\
\text { penyusunan neraca dan laporan } \\
\text { laba rugi pada laporan keuangan. }\end{array}$ & 0,05 & 4 & 0,20 \\
\hline $\begin{array}{l}\text { e. Gapoktan belum memiliki } \\
\text { sekretariat khusus. }\end{array}$ & 0,05 & 3 & 0,15 \\
\hline $\begin{array}{l}\text { f. Gapoktan tidak memliki alat-alat } \\
\text { pertanian yang modern untuk } \\
\text { pengembangan usaha tani. }\end{array}$ & 0,03 & 3 & 0,09 \\
\hline $\begin{array}{l}\text { g. Gapoktan belum memiliki badan } \\
\text { hukum. }\end{array}$ & 0,05 & 4 & 0,20 \\
\hline Total & $\mathbf{1 , 0 0}$ & & $\mathbf{1 , 5 2}$ \\
\hline
\end{tabular}

\subsubsection{Tahap Pencocokan}

Setelah menganalisis data menggunakan matriks EFE dan IFE dalam tahap input, maka selanjutnya masuk ke tahap analisis atau pencocokan. Pada tahap analisis ini peluang dan ancaman pada faktor eksternal dipadukan dengan kekuatan dan kelemahan pada faktor internal. Tahap analisis ini merupakan kunci untuk menciptakan strategi alternatif yang masuk akal. Analisis yang digunakan adalah analisis SWOT. Analisis SWOT dipakai untuk melihat strategi apa saja yang dapat digunakan yang disesuaikan dengan kondisi eksternal dan internal saat ini.

Tabel 4.19

Matriks SWOT Gapoktan Kabupaten Kuningan

\begin{tabular}{|l|l|l|}
\hline Faktor Internal & Kekuatan (S) & Kelemahan (W) \\
& $\begin{array}{l}\text { Jumlah SDM yang } \\
\text { mencukupi untuk } \\
\text { membentu LKMA. }\end{array}$ & $\begin{array}{l}\text { Sebagian gapoktan } \\
\text { masih menganggap } \\
\text { dana pinjaman }\end{array}$ \\
& & PUAP adalah dana \\
\hline
\end{tabular}




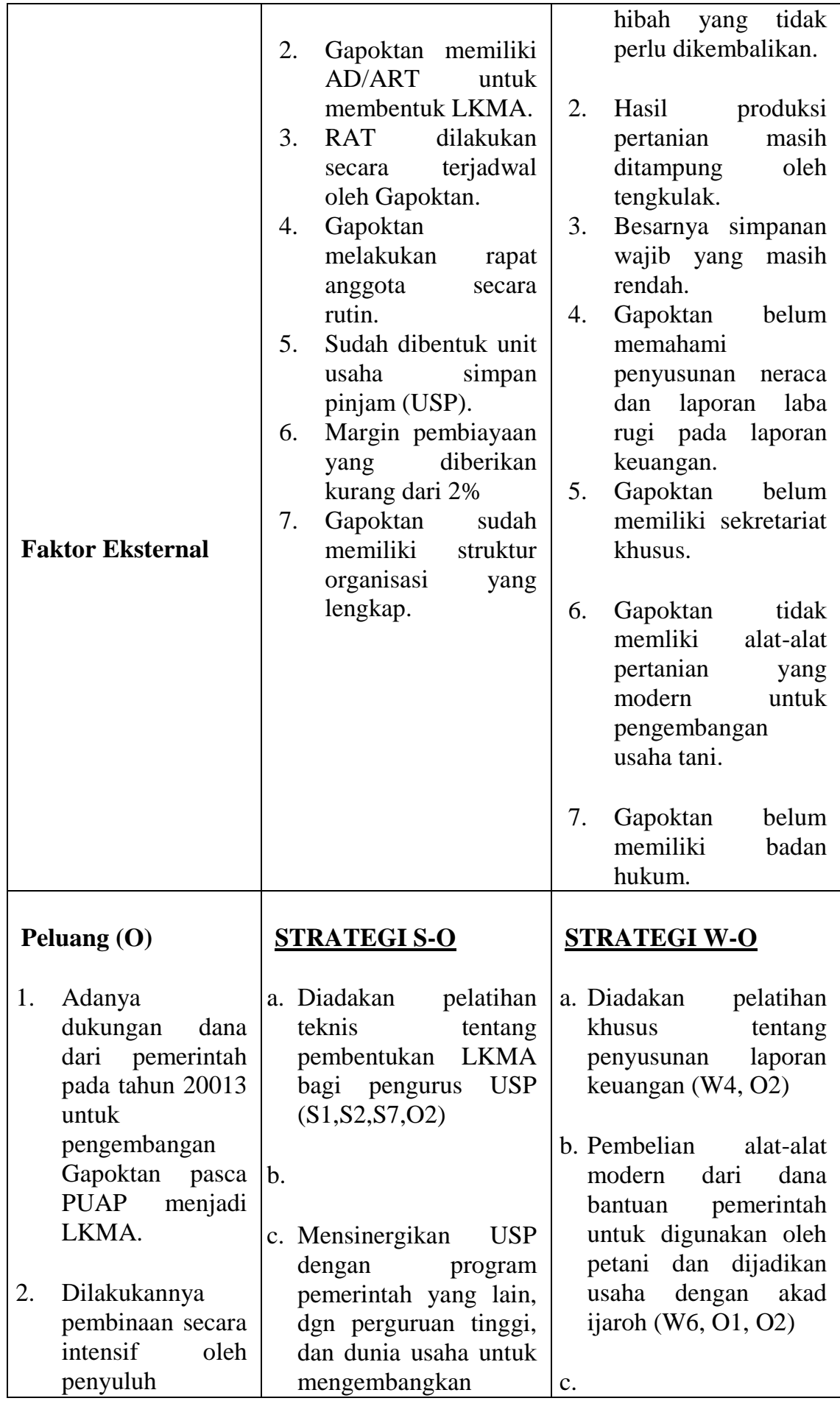




\begin{tabular}{|c|c|c|}
\hline 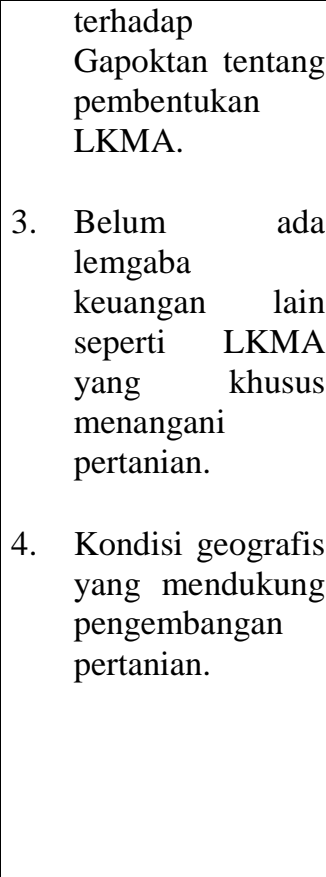 & $\begin{array}{l}\text { kapasitas } \\
\text { kelembagaaan (S5, } \\
\text { O2) } \\
\text { d. Membuat Jobdesk } \\
\text { untuk memaksimalkan } \\
\text { fungsi masing-masing } \\
\text { tingkatan pada struktur } \\
\text { organisasi (S7, O2) } \\
\text { e. USP membuka produk } \\
\text { tabungan bagi } \\
\text { anggotanya (S5, O3) }\end{array}$ & $\begin{array}{l}\text { d. Diadakan perjanjian } \\
\text { dengan anggota untuk } \\
\text { mengembalikan } \\
\text { pinjaman sesuai akad } \\
\text { awal (W1, O2) } \\
\text { e. Tim PUAP Kabupaten } \\
\text { memberlakukan } \\
\text { standar minimal } \\
\text { besarnya simpanan } \\
\text { wajib bagi gapoktan } \\
\text { (W3, O2) } \\
\text { f. Gapoktan diarahkan } \\
\text { untuk untuk } \\
\text { menggunakan software } \\
\text { CMBS (Core Micro } \\
\text { Banking System) untuk } \\
\text { memudahkan dalam } \\
\text { pelaporan keuangan } \\
\text { (W4, O2) }\end{array}$ \\
\hline Ancaman (T) & STRATEGI S-T & STRATEGI W-T \\
\hline $\begin{array}{l}\text { 1. Tingkat resiko } \\
\text { yang tinggi pada } \\
\text { usaha pertanian } \\
\text { 2. Tidak adanya } \\
\text { pelatihan khusus } \\
\text { pengelolaan }\end{array}$ & \begin{tabular}{ll} 
a. Gapoktan & \\
menunjukkan & potensi \\
daerahnya & masing- \\
masing & dengan \\
mengikuti berbagai & \\
\multicolumn{2}{l}{ macam pameran untuk }
\end{tabular} & $\begin{array}{l}\text { a. Mengadakan } \\
\text { sosialisasi pedoman } \\
\text { umum PUAP/ juknis } \\
\text { pengelolaan dana } \\
\text { PUAP pasa anggota } \\
\text { gapoktan }(\mathrm{W} 1, \mathrm{~T} 2)\end{array}$ \\
\hline $\begin{array}{l}\text { pinjam. } \\
\text { 3. Rendahnya } \\
\text { tingkat investasi } \\
\text { di rektor } \\
\text { pertanian yang } \\
\text { hanya mencapai } \\
\text { o,23\%. }\end{array}$ & $\begin{array}{l}\text { (S1, T3) } \\
\text { b. Diadakan sosialisasi } \\
\text { dan penyuluhan pada } \\
\text { anggota ralam } \\
\text { rapat/RAT tentang } \\
\begin{array}{l}\text { bahaya } \\
\text { rentenir }(\mathrm{S} 3, \mathrm{~S} 4, \mathrm{~T} 4)\end{array}\end{array}$ & 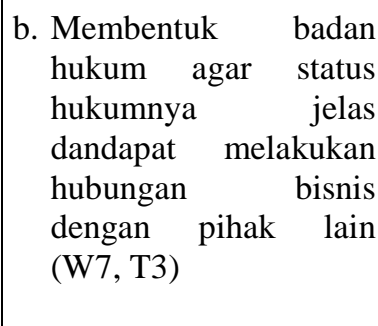 \\
\hline $\begin{array}{l}\text { Masih banyaknya } \\
\text { bank keliling. }\end{array}$ & $\begin{array}{l}\text { c. Mengadakan pelatihan } \\
\text { pengelolaan USP (S1, } \\
\text { S5, T2) }\end{array}$ & $\begin{array}{l}\text { c. Memperbaiki fungsi } \\
\text { organisasi gapoktan } \\
\text { untuk meningkatkan } \\
\text { kinerja USP (W7, T2) }\end{array}$ \\
\hline & $\begin{array}{l}\text { d. Menyelenggarakan } \\
\text { studi banding dengan } \\
\text { KUD atau lembaga }\end{array}$ & $\begin{array}{l}\text { d. Melakukan hedging / } \\
\text { lindung nilai barang } \\
\text { pertanian agar resiko }\end{array}$ \\
\hline
\end{tabular}




\begin{tabular}{|l|l|l|}
\hline & $\begin{array}{l}\text { keuangan lainnya } \\
\text { untuk meningkatkan } \\
\text { kinerja USP (S1, S5, } \\
\text { S7, T2) }\end{array}$ & $\begin{array}{l}\text { pertanian dapat ditekan } \\
(\mathrm{W} 2, \mathrm{~T} 4)\end{array}$ \\
\hline
\end{tabular}

Sumber : data hasil wawancara penulis dengan gapoktan

Dari matriks SWOT yang telah disusun di atas, didapat kombinasi strategi-strategi sebagai hasil dari pengembangan pengolahan data-data internal dan eksternal Gapoktan. Berdasarkan Tabel Matriks SWOT diatas dapat dijabarkan rumusan strategi sebagai berikut :

\section{a. Strategi S-O}

Strategi S-O merupakan penggabungan dari Kekuatan dan Peluang dengan memanfaatkan kekuatan internal untuk menarik keuntungan dari peluang eksternal. Strategi S-O dalam pengembangan usaha agribisnis perdesaan adalah :

1. Diadakan pelatihan teknis tentang pembentukan LKMA bagi pengurus USP $(\mathrm{S} 1, \mathrm{~S} 2, \mathrm{~S} 7, \mathrm{O} 2)$

2. Mensinergikan USP dengan program pemerintah yang lain, dgn perguruan tinggi, dan dunia usaha untuk mengembangkan kapasitas kelembagaaan (S5, O2)

3. Membuat Jobdesk untuk memaksimalkan fungsi masingmasing tingkatan pada struktur organisasi $(\mathrm{S} 7, \mathrm{O} 2)$

4. USP membuka produk tabungan bagi anggotanya (S5, O3)

b. Strategi W-O

Strategi W-O merupakan penggabungan dari faktor internal kelemahan dengan faktor eksternal peluang dengan cara memperbaiki kelemahan internal dan memanfaatkan peluang eksternal. Strategi W-O dalam pengembangan usaha agribisnis perdesaan adalah :

1. Diadakan pelatihan khusus tentang penyusunan laporan keuangan (W4, O2)

2. Pembelian alat-alat modern dari dana bantuan pemerintah untuk digunakan oleh petani dan dijadikan usaha dengan akad ijaroh (W6, O1, O2)

3. Diadakan perjanjian dengan anggota untuk mengembalikan pinjaman sesuai akad awal (W1, O2)

4. Tim PUAP Kabupaten memberlakukan standar minimal besarnya simpanan wajib bagi gapoktan (W3, O2)

5. Gapoktan diarahkan untuk untuk menggunakan software CMBS (Core Micro Banking System) untuk memudahkan dalam pelaporan keuangan $(\mathrm{W} 4, \mathrm{O} 2)$ 
c. Strategi S-T merupakan penggabungan antara faktor internal kekuatan dan faktor eksternal ancamandengan cara menggunakan kekuatan yang dimiliki untuk menghindari atau mengurangi dampak ancaman eksternal. Strategi W-T dalam pengembangan usaha agribisnis perdesaan adalah :

1. Gapoktan menunjukkan potensi daerahnya masing-masing dengan mengikuti berbagai macam pameran untuk dapat menarik investor (S1, T3)

2. Diadakan sosialisasi dan penyuluhan pada anggota dalam rapat/RAT tentang bahaya kegiatan rentenir (S3, S4, T4)

3. Mengadakan pelatihan pengelolaan USP (S1, S5, T2)

4. Menyelenggarakan studi banding dengan KUD atau lembaga keuangan lainnya untuk meningkatkan kinerja USP (S1, S5, S7, T2)

d. Strategi W-T merupakan penggabungan antara faktor internal kelemahan dan faktor eksternal ancaman. Strategi W-T ini merupakan strategi defensif yang diarahkan untuk mengurangi kelemahan internal serta menghindari ancaman eksternal. Strategi W-T dalam pengembangan usaha agribisnis perdesaan adalah :

1. Mengadakan sosialisasi pedoman umum PUAP/ juknis pengelolaan dana PUAP pasa anggota gapoktan (W1, T2)

2. Membentuk badan hukum agar status hukumnya jelas dandapat melakukan hubungan bisnis dengan pihak lain (W7, T3)

3. Memperbaiki fungsi organisasi gapoktan untuk meningkatkan kinerja USP (W7, T2)

4. Melakukan hedging / lindung nilai barang pertanian agar resiko pertanian dapat ditekan (W2, T4)

Selanjutnya akan ditentukan posisi Gapoktan berada di kuadran mana. Untuk mengetahui posisi kuadran gapoktan dapat dilihat melalui hasil matriks EFE dan IFE. Hasil dari pengolahan matriks EFE dan IFE ini adalah untuk melihat posisi gapoktan yang nantinya akan dijadikan sebagai pertimbangan dalam mengambil strategi yang akan dijalankan. Pembentukan sumbu-sumbu pada kuadran diambil dari :

a. Sumbu $\mathrm{X}$ adalah hasil pengurangan dari total skor kekuatan dikurangi kelemahan. Sehingga :

$$
\begin{aligned}
& X=1,42-1,52 \\
& X=-0,10
\end{aligned}
$$

b. Sumbu $\mathrm{Y}$ adalah hasil pengurangan dari total skor peluang dikurangi total skor ancaman. Sehingga :

$$
\begin{aligned}
& \mathrm{Y}=2,03-1,2 \\
& \mathrm{Y}=0,83
\end{aligned}
$$




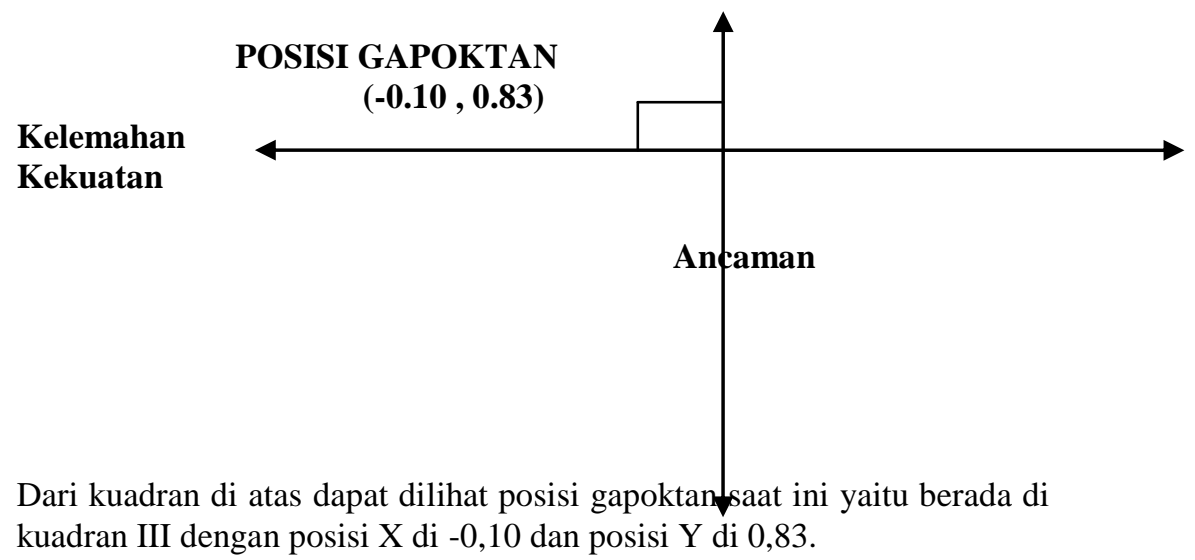

\subsubsection{Tahap Pengambilan keputusan}

Melalui tahap analisis di atas, diketahui posisi gapoktan berada pada kuadran I yang didapat dari hasil analisis SWOT, matriks EFE dan matriks IFE. Posisi ini berarti gapoktan berada dalam posisi yang kuat dengan kekuatan internal yang dapat diandalkan dan memiliki peluang besar. Berdasarkan matriks SWOT telah didapat alternatif strategi WO (Weakness - Opportunity). Adapun alternatif strateginya adalah sebagai berikut :

1. Diadakan pelatihan khusus tentang penyusunan laporan keuangan (W4, O2)

2. Pembelian alat-alat modern dari dana bantuan pemerintah untuk digunakan oleh petani dan dijadikan usaha dengan akad ijaroh (W6, O1, O2)

3. Diadakan perjanjian dengan anggota untuk mengembalikan pinjaman sesuai akad awal (W1, O2)

4. Tim PUAP Kabupaten memberlakukan standar minimal besarnya simpanan wajib bagi gapoktan (W3, O2)

5. Gapoktan diarahkan untuk untuk menggunakan software CMBS (Core Micro Banking System) untuk memudahkan dalam pelaporan keuangan (W4, O2)

Selanjutnya adalah tahap mengambil keputusan tentang strategi yang akan diambil dengan menggunakan Matriks QSPM yaitu matriks perencanaan strategi kuantitatif. Berikut adalah tabel matriks QSPM: 


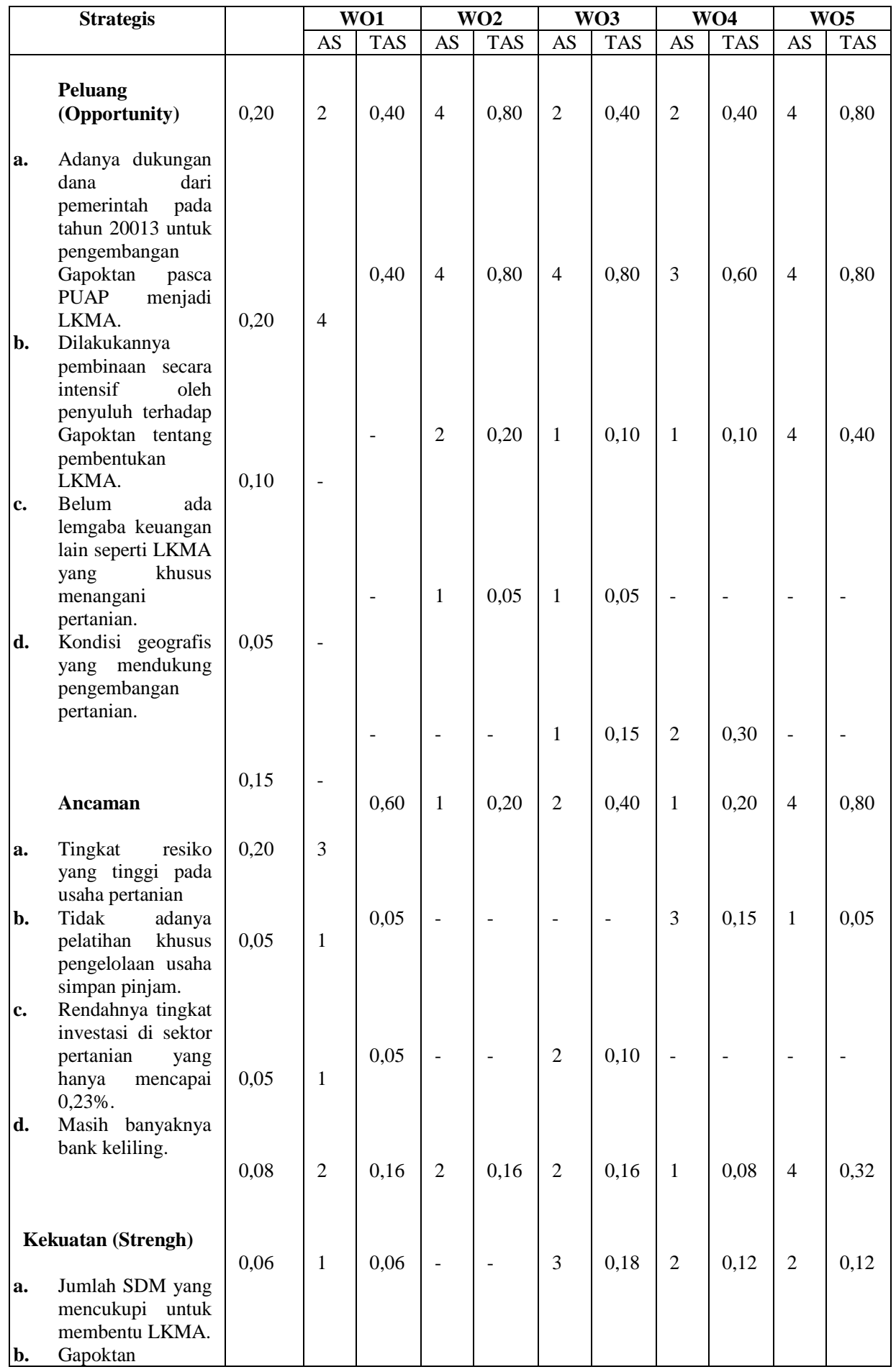




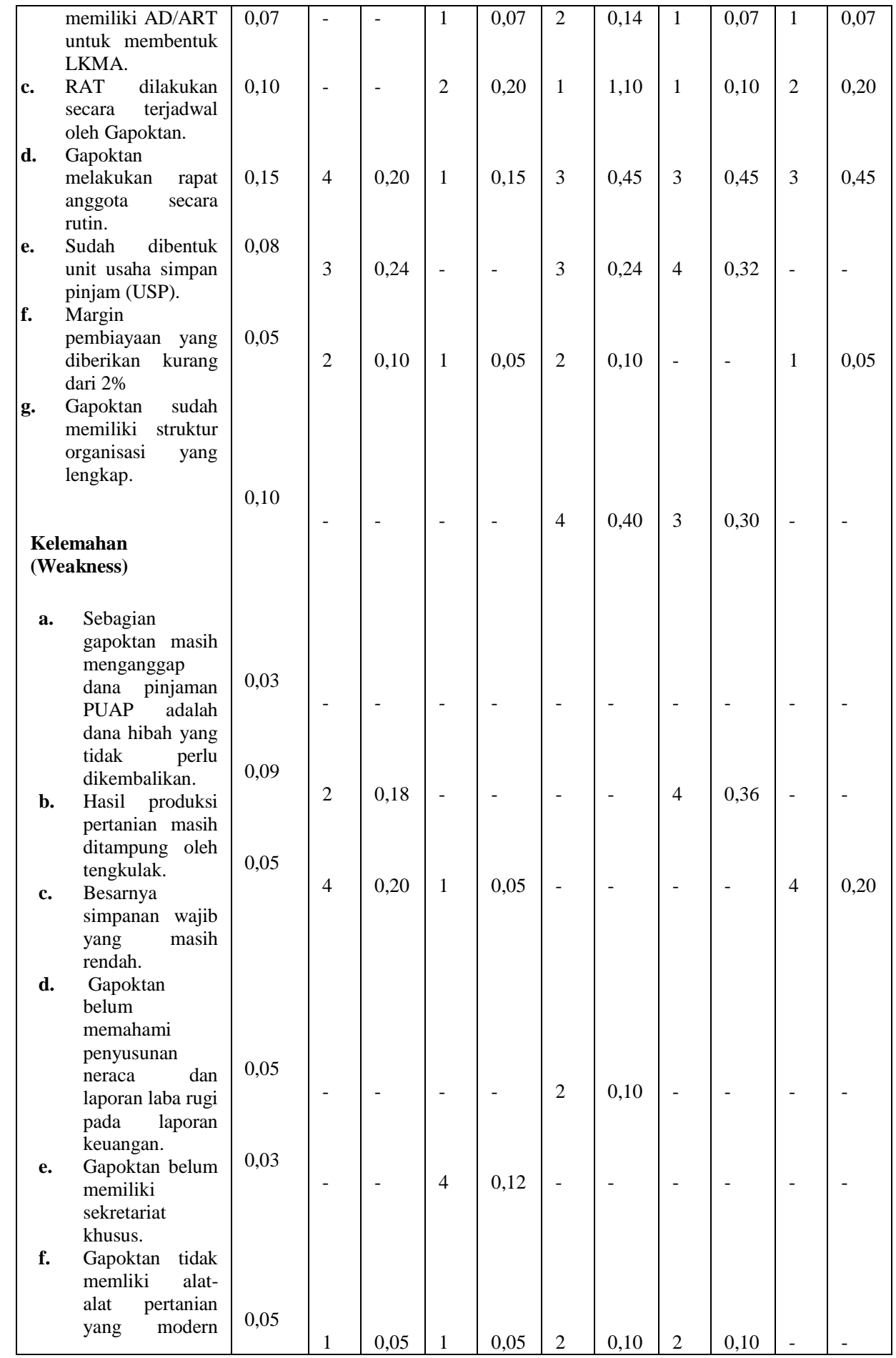




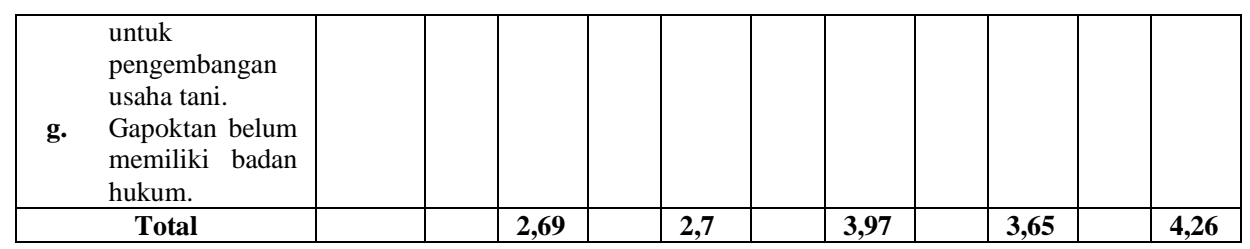

AS = Nilai Daya Tarik

TAS $=$ Total Nilai Daya Tarik

Dari matriks QSPM di atas, dapat dilihat bahwa total kemenarikan relatif dari alternatif strategi secara berurutan adalah :

1. Gapoktan diarahkan untuk untuk menggunakan software CMBS (Core Micro Banking System) untuk memudahkan dalam pelaporan keuangan $(4,26)$

2. Diadakan perjanjian dengan anggota untuk mengembalikan pinjaman sesuai akad awal $(3,97)$

3. Tim PUAP Kabupaten memberlakukan standar minimal besarnya simpanan wajib bagi gapoktan $(3,65)$

4. Diadakan pelatihan khusus tentang penyusunan laporan keuangan $(2,69)$

5. Pembelian alat-alat modern dari dana bantuan pemerintah untuk digunakan oleh petani dan dijadikan usaha dengan akad ijaroh $(2,7)$

\section{BAB V Penutup}

Berdasarkan penelitian yang telah diuraikan mengenai dalam bab sebelumnya, penulis menarik beberapa kesimpulan dan strategi yang dapat dipakai Gapoktan dalam pembentukan lembaga keuangan mikro agribisnis.

Dari hasil analisis SWOT didapat beberapa alternatif strategi dari hasil penggabungan antara faktor-faktor eksternal dan internal. Dari strategi-strategi yang terbentuk ini, didapat alternatif strategi yang sesuai dengan kondisi Gapoktan di kabupaten Kuningan yang berada di kuadran I. Posisi kuadran I didapat dengan cara menghitung melalui matriks EFE dan IFE. Berikut adalah altrenatif strategi yang dapat diambil :

1. Gapoktan diarahkan untuk untuk menggunakan software CMBS (Core Micro Banking System) untuk memudahkan dalam pelaporan keuangan

2. Diadakan perjanjian dengan anggota untuk mengembalikan pinjaman sesuai akad awal

3. Tim PUAP Kabupaten memberlakukan standar minimal besarnya simpanan wajib bagi gapoktan

4. Diadakan pelatihan khusus tentang penyusunan laporan keuangan

5. Pembelian alat-alat modern dari dana bantuan pemerintah untuk digunakan oleh petani dan dijadikan usaha dengan akad ijaroh 
Setelah itu diambil keputusan melalui QSPM, strategi mana yang cocok sesuai dengan daya tarik antara faktor internal eksternal dengan strategi yang dibentuk. Berdasarkan hasil analisis dengan QSPM, didapat daya tarik tertinggi sebilai 6,02 yaitu pada strategi : Gapoktan diarahkan untuk untuk menggunakan software CMBS (Core Micro Banking System) untuk memudahkan dalam pelaporan keuangan $(4,26)$

\section{DAFTAR PUSTAKA}

Anonimus. (2007).

Bappeda. (2012). Kab.Kuningan.

BP4K. (2012). Kabupaten Kuningan.

Erickson, W. D. (1992). Manajemen Agribisnis (Edisi Kedua). Jakarta: Erlangga.

Jauch, L. R. (1996). manajemen Strategis dan kebijakan perusahaan (Edisi ketiga). Jakarta: Erlangga.

Kuningan, P. (2012).

Pedum. (2012). Dalam PUAP (hal. 12).

Pertanian, K. (2009). Jakarta.

Pertanian, K. (2011).

Purwanto, I. (1999). Managemen Strategi.

R.David, F. (2006). Manajemen Strategis I (Edisi 10). jakarta: Salemba Empat.

rangkuti, F. (2006). Analisis SWOT teknik membedah kasus bisnis. Jakarta: Gramedia Pustaka Utama.

Said, E. G. (2004). Manajemen teknologi Agribisnis. Jakarta: PT Ghalia Indonesia dengan MMA-IPB.

Saladin, h. D. (2004). Manajemen Strategik dan Kebijakan Perusahaan. Bandung: Linda.

Statistik, B. P. (2012).

Sugiyono. (2012). Metode penelitian kombinasi. Bandung: CV Alfabeta. Sugiyono. (2009). Metode penelitian Kuantitatif, Kualitatif dan R\&D. bandung: CV Alfabeta.

Suharsimi, A. (2002). Prosedur Penelitian (Edisi Revisi). Jakarta: Rineka Cipta.

TNP2K. (2012).

Wijono. (t.thn.). Pemberdayaan $1 \mathrm{~km}$ sebagai salah satu pilar sistem keuangan nasional. 